This is the final peer-reviewed accepted manuscript of

Cristino S.; Zapater-Pereyra M.; Vymazal J.; Cupido D.; Lucchese G.; Mancini B.; Mancini M. L.; Lavrnic S: Effect of earthworms and plants on the efficiency of vertical flow systems treating university wastewater. ENVIRONMENTAL SCIENCE AND POLLUTION RESEARCH INTERNATIONAL, 26. ISSN 1614-7499

DOI: $10.1007 / s 11356-019-04508-4$

The final published version is available online at:

http://dx.doi.org/10.1007/s11356-019-04508-4

Rights / License: The terms and conditions for the reuse of this version of the manuscript are specified in the publishing policy. For all terms of use and more information see the publisher's website. 


\title{
Effect of earthworms and plants on the efficiency of vertical flow systems treating university wastewater
}

\author{
Stevo Lavrnić ${ }^{1,2} \cdot$ Sandra Cristino $^{3} \cdot$ Maribel Zapater-Pereyra $^{4} \cdot$ Jan Vymazal $^{5} \cdot$ Domenico Cupido $^{2}$. \\ Giovanni Lucchese $^{2} \cdot$ Benedetta Mancini $^{3} \cdot$ Maurizio L. Mancini ${ }^{2}$
}

\begin{abstract}
One of the possible ways to improve the operation efficiency of constructed wetlands and to prevent their clogging is the application of earthworms. They have already been successfully applied for vermicomposting and for sludge dewatering and treatment. A few studies have already examined the effect of earthworms on the treatment of waste-water by vertical flow constructed wetlands (VFCWs), but none of them have provided a yearlong research result from an open-air system or compared the effect that different seasons in a temperate climate area can have on these invertebrates. The goal of this research was to estimate the effect that earthworms and plants have on VFCW's operation. Four mesocosms (a filter, a filter with earthworms, a VFCW and a VFCW with earthworms) were built and their influent and effluent water quality was monitored for a period of 1 year. They were fed with wastewater coming from a building of the University of Bologna (Italy). The results have shown that the presence of earthworms in this specific system did not reduce the organic matter content of the substrate, but it has positively influenced plants' growth. However, since neither earthworms nor plants had a statistically significant effect on the effluent quality, it can be concluded that the integration of these invertebrates cannot improve wastewater treatment of vertical flow filters or constructed wetlands.
\end{abstract}

Keywords Constructed wetlands $\cdot$ Earthworms $\cdot$ Filters $\cdot$ Plants $\cdot$ Seasonal effect $\cdot$ Wastewater treatment

Responsible editor: Philippe Garrigues

Electronic supplementary material The online version of this article (https://doi.org/10.1007/s11356 $019 \quad 04508$ 4) contains supplementary material, which is available to authorized users.

Stevo Lavrnić

stevo.lavrnic@unibo.it

1 Campus de Puerto Real, University of Cádiz, Polígono San Pedro s/n, Puerto Real, 11519 Cádiz, Spain

2 Dipartimento di Ingegneria Civile, Chimica, Ambientale e dei Materiali, University of Bologna, Via Umberto Terracini 28, 40131 Bologna, Italy

3 Dipartimento di Scienze Biologiche, Geologiche e Ambientali, University of Bologna, Via San Giacomo 12, 40126 Bologna, Italy

4 Independent researcher, Gottfried Keller Str, 25 81245 Munich, Germany

5 Faculty of Environmental Sciences, Czech University of Life Sciences Prague, Kamycka 129, 16521 Praha 6, Czech Republic

\section{Introduction}

Constructed wetlands are engineered systems that mimic processes occurring in natural wetlands to treat waste-water. What makes them so suitable is that their con-struction costs, operation, and maintenance requirements are lower compared to the conventional wastewater treatment plants (Nivala et al. 2012). Moreover, they can be well integrated into the environment (Zapater-Pereyra et al. 2015) and they do not require specifically trained personnel (Li et al. 2011; Nivala et al. 2012; Wu et al. 2013). The use of constructed wetlands has spread in the past few decades, and a growing number of stud-ies have focused on their operation, but they still face certain difficulties such as clogging and poor nutrient removal (Meng et al. 2014; Lavrnić and Mancini 2016). The presence of earthworms has been reported in con-structed wetlands (Nuengjamnong 2010), and Chen et al.(2016) stated that vertical flow constructed wetlands can be a viable habitat for these invertebrates since they 
prefer dark, humid, oxygenated, and environments rich in organic matter ( $\mathrm{Li}$ et al. 2011). They ingest a mixture of organic matter and sand, the latter one having a role in breaking organic material ( $\mathrm{Li}$ et al. 2011), and they also consume microorganisms present in the soil. Due to the favourable conditions inside the earthworms' gut, these microorganisms rapidly multiply and are later excreted by earthworms back to the environment (Le Bayon and Milleret 2009). It has been established that the presence of earthworms can increase plant growth and crop yields (Edwards and Bater 1992). Moreover, they can increase the air presence in the filter bed by consuming accumulated organic solids and by breaking the compacted substrate (Arora and Kazmi 2015).

Earthworms have previously been successfully applied for composting and stabilisation of organic material (vermicompost), and the final product of this process (humic substances) has a high potential for adsorption of metals (Matos and Arruda 2003). Vermicompost can also be used for soil amendment and can increase plant growth (Ngo et al. 2012). Moreover, earthworms were used for sludge dewatering, stabilisation, and reduction (Tamis et al. 2011; Chen et al. 2016), and it was reported that they can prevent clogging and restore already clogged vertical flow constructed wetlands ( $\mathrm{Li}$ et al. 2011; Nivala et al. 2012). Temperature is a very important parameter for these organisms. For example, growth rate for Eisenia foetida was found to be higher at $30{ }^{\circ} \mathrm{C}$ than in lower temperatures, but optimal temperature for their reproduction was $20{ }^{\circ} \mathrm{C}$ (Edwards and Bater 1992). Even though there are some studies that have examined the influence of earthworms on the different treatment aspects of constructed wetlands or filters (Taylor et al. 2003; Li et al. 2011; Nuengjamnong et al. 2011; Tomar and Suthar 2011; Xu et al. 2012, 2013a, b, c; Wu et al. 2013; Arora and Kazmi 2015; Chen et al. 2016; Singh et al. 2018), to the authors' best knowledge, none of them provided a yearlong result from an open-air system treating real domestic wastewater, or compared the effect that the different seasons in temperate climate areas have on the performance of these systems. Temperature was shown to influence removal efficiencies of CWs (Zhou et al. 2017), and therefore, it is important to consider it as an experimental factor. If earthworms could be successfully used in CWs and improve their performance during different seasons, it would further lower the costs of this technology and make it more robust and efficient.

Therefore, the main objective of this research was to evaluate the effect that earthworms have on the performance of a vertical flow filter and vertical flow constructed wetland. In addition, the effect that plants (Phragmites australis) or different seasons have on the performance of these systems was also evaluated.

\section{Materials and methods}

\section{Effect of earthworms and plants}

\section{Experimental set-up (pilot scale)}

The pilot plant (Fig. 1) was located at one of the buildings of the Department of Civil, Chemical, Environmental and Materials Engineering (DICAM) at the University of Bologna (Italy). Primary treatment was done by a septic tank, which was followed by an inflow tank that distributes the wastewater to four vertical flow mesocosms $(\varnothing 0.48 \mathrm{~m}$, $0.55 \mathrm{~m}$ depth): filter $(\mathrm{F})$, constructed wetland without earthworms $(\mathrm{CW})$, constructed wetland with earthworms $(\mathrm{CWw})$, and filter with earthworms (Fw). All mesocosms were filled with $12 \mathrm{~cm}$ of gravel at the bottom $(\varnothing 0.63-5 \mathrm{~cm})$ and topped with $33 \mathrm{~cm}$ of sand (Ø $2-4 \mathrm{~mm})$. Passive aeration was applied using two vertical aeration tubes open to the atmosphere. The inlet water was distributed by means of plastic pipes placed on the top of the substrate.

The mesocosms were built in April 2015 and two of them were immediately planted with Phragmites australis (CW and $\mathrm{CWw}$ ) at an initial plant density of 55 plants $\mathrm{m}^{2}$. The systems were monitored for 1 year (October 2015-October 2016), and the dataset was divided in four seasons, according to the mean daily temperatures (Table 1).

The mesocosms were operated in a batch mode under saturated conditions, outlet valve allowing manual control of water drainage. During the warm period of the year (AprilOctober), the mesocosms received $15 \mathrm{~L}$ of water 3 times a week and the outlet valves were opened after $24 \mathrm{~h}$. In order to prevent drying of the plants during the weekend, $10 \mathrm{~L}$ of water was added every Friday evening and it was discharged on Monday morning, but its quality was not analysed. Conversely, during the cold period (October-April), the mesocosms received $15 \mathrm{~L}$ twice per week, the retention time was $48 \mathrm{~h}$ and no water was added over the weekend. A precise schedule prepared in advance was followed when managing the pilot plant, and the systems were left dry for a set period of time before each batch of water was added.

The earthworms used in $\mathrm{CWw}$ and $\mathrm{Fw}$ were first obtained from the natural soil near the pilot plant, but afterwards (since July 2016), they were purchased in a fishing equipment shop. Before being transferred to a mesocosm, earthworms were kept in a mixture of sand (identical to that used in the systems) and humus, in order to prevent the negative effect that a sudden change of environment could have on them. Every 34 weeks, an average of $3.5 \mathrm{~g}$ of the earthworms (approximately 10 individuals) were added to the $\mathrm{CWw}$ and $\mathrm{Fw}$, which represents the density of $0.1 \mathrm{~g} \mathrm{~L}_{\text {substrate }}{ }^{1}$ or 0.25 individuals $\mathrm{L}_{\text {substrate }}{ }^{1}$ added every time. These additions were performed since growth and reproduction of the earthworm inside the system could not be monitored, and in order to ensure their 


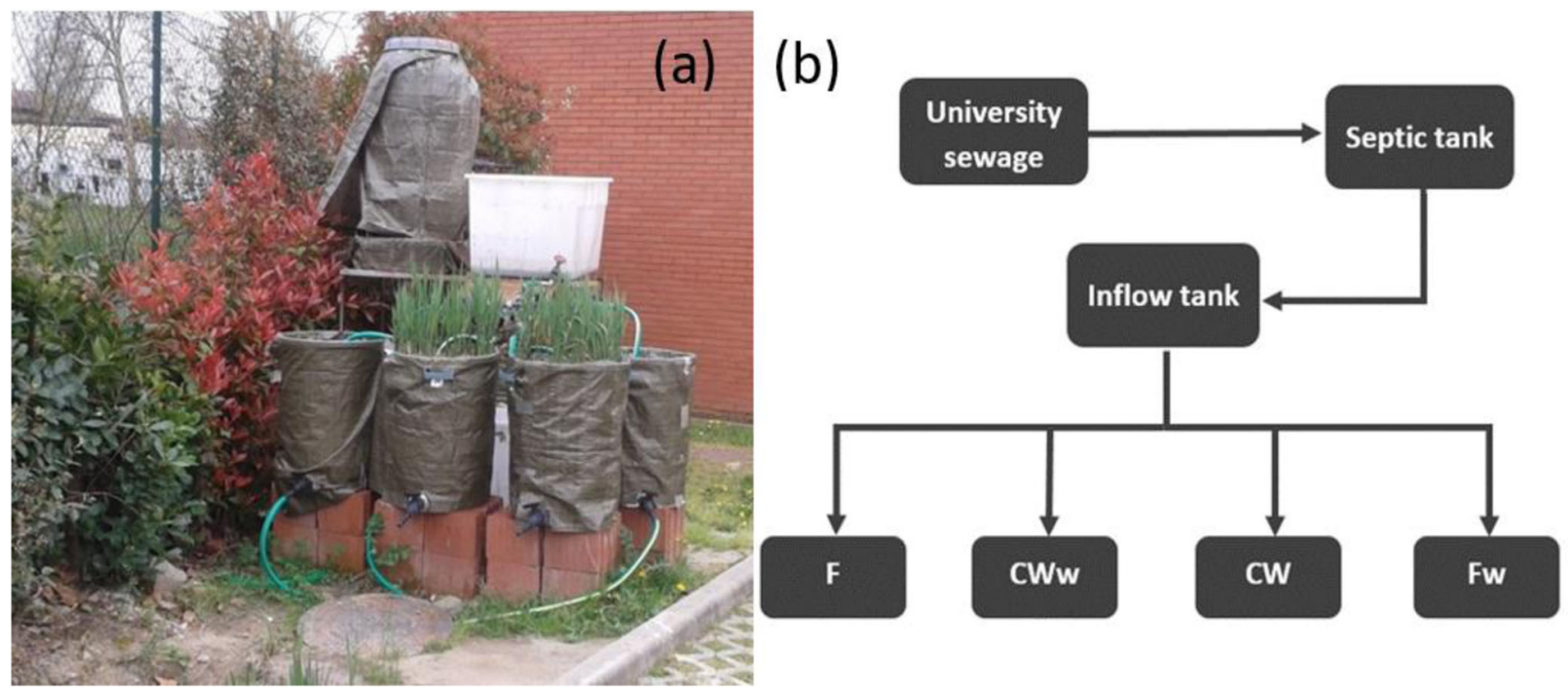

Fig. 1 Pilot plant in March 2016 (a) and a schematic representation of the water flow in the system (b). F Filter, CWw constructed wetland with earthworms, CW constructed wetland, Fw Filter with earthworms. All the systems are vertical flow

constant presence in $\mathrm{CWw}$ and $\mathrm{Fw}$. In order to avoid excessive waterlogging and the subsequent death of the earthworms, the upper $22 \mathrm{~cm}$ of the substrate (approximately $40 \mathrm{~L}$ ) was kept unsaturated. Unfortunately, it was not possible to determine the exact species of the earthworms used.

\section{Experimental design and analytical methods}

During the experimental period, influents and effluents from the four mesocosms were tested for different water quality parameters approximately every $3-4$ weeks. The results ob-tained were averaged for the whole experimental period and also for each studied season as shown in Table 1. Samples were analysed for $\mathrm{pH}$ by the electrometric method, chemical oxygen demand (COD) spectrophotometrically with a COD Vario cuvette kit (Aqualytic, Germany) and total suspended solids (TSS) by the gravimetric method. Total nitrogen (TN) and total phosphorus (TP) were analysed by digestion by the persulfate method followed by measurements of $\mathrm{NO}_{3}-\mathrm{N}$ (ul-traviolet spectrophotometric screening method) and $\mathrm{PO}_{4}{ }^{3}$-P (vanadomolybdophosphoric acid colorimetric method),

\begin{tabular}{|c|c|c|c|c|}
\hline & Beginning date & Ending date & Average air temperature $\left({ }^{\circ} \mathrm{C}\right)$ & HRT (days) \\
\hline Table 1 & Experimental periods of the pilot plant & & Mean \pm st. error (n) & \\
\hline Autumn & 20th October 2015 & 20th November 2015 & $12.5 \pm 03(32)$ & $\begin{array}{l}1 \text { (until } 9 \text { November) } \\
2 \text { (from } 10 \text { November) }\end{array}$ \\
\hline Winter & 21st November 2015 & 17th March 2016 & $6.9 \pm 0.2(115)$ & 2 \\
\hline Spring & 18th March 2016 & 19th June 2016 & $18.3 \pm 0.4(94)$ & $\begin{array}{l}2 \text { (until } 31 \text { March) } \\
1 \text { (from } 1 \text { April) }\end{array}$ \\
\hline Summer & 20th June 2015 & 14th September 2016 & $27.0 \pm 03(87)$ & 1 \\
\hline
\end{tabular}

respectively. Finally, different ions such as nitrate $\left(\mathrm{NO}_{3}\right)$, nitrite $\left(\mathrm{NO}_{2}\right)$, phosphate $\left(\mathrm{PO}_{4}{ }^{3}\right)$, chloride $(\mathrm{Cl})$, bromide $(\mathrm{Br})$ and sulphate $\left(\mathrm{SO}_{4}{ }^{2}\right)$ were analysed by ion chromatography (DX-120, Dionex Corporation, USA). These analyses were performed following APHA (2005) unless stated otherwise. Measurement of ammonia $\left(\mathrm{NH}_{4}{ }^{+}\right)$was not possible due to technical problems. The microbiological parameters (E. coli, total coliforms and Enterococcus) were analysed by the membrane filter technique, which permits to retain/ concentrate the contaminants (bacteria) found in the sample, followed by incubation and enumeration using a chromogenic coliform agar for E. coli and total coliforms (UNI EN ISO 9308-1 2014) and a Slanetz Bartley Agar for Enterococcus (EN ISO 7899-2 2000).

The above-ground biomass of the plants was harvested at the beginning of summer ( 7 June 2016, after 8.5 months of operation) and at the end of the experimental period (6 October 2016, after 1 year of operation). The dry weight was recorded after drying for at least $48 \mathrm{~h}$ at $105^{\circ} \mathrm{C}$. The length of the longest shoot from both $\mathrm{CW}$ and $\mathrm{CWw}$ was also measured on the 6th of October. 
Air temperature was recorded every 5 min during the whole experimental period by the instruments operated by CIRI (Interdepartmental Centres for Industrial Research) in the vicinity to the pilot plant (approximately $150 \mathrm{~m}$ ).

\section{Effect of earthworms on the substrate}

\section{Experimental set-up (microcosm)}

The accumulation of organic matter in the substrate was identified as one of the causes of clogging in constructed wetlands (Nivala et al. 2012). In order to assess the effect that the earthworms have on the substrate's organic matter content (OMC) and to estimate their growth, a separate small-scale experiment was conducted. For that purpose, three microcosms were installed $(20 \times 25 \times$ $20 \mathrm{~cm}$, width $\times$ length $\times$ height). Two microcosms were used to simulate the mesocosms from "Experimental set-up (pilot scale)": a reactor with earthworms and a reactor without them, both filled with coarse sand (Ø: 2-4 mm). Before beginning the experiments and adding the earthworms, the filters were fed with raw wastewater for 2 weeks. This was done to allow an increase of the OMC of the substrate, simulating better the conditions usually present inside a running system (filter and constructed wetland). During the experiment, these two filters had the same feeding schedule as the vertical flow mesocosms ("Experimental set-up (pilot scale)"), but due to the size difference, it was only $1 \mathrm{~L}$ of wastewater each time. The third microcosm was a reactor that represented the conditions in the top layer of the soil from where earthworms were obtained. It also contained these invertebrates, but instead of sand, it was filled with soil and plant biomass taken from the same area as the earthworms. This reactor received $1 \mathrm{~L}$ of tap water once a week, and its retention time was 6 days.

\section{Experimental design and analytical methods}

This experiment was conducted for 2 months (MayJuly 2016). Substrate samples were taken at the beginning and the end of the experiment (19th May and 14th July) and stored at $-20{ }^{\circ} \mathrm{C}$ (for few weeks) to be analysed for $\mathrm{OMC}$ as loss on ignition at $550{ }^{\circ} \mathrm{C}$ after drying to constant weight at $80{ }^{\circ} \mathrm{C}$ (Tanner and Sukias 1995). This procedure could not be done with the substrate of the four mesocosms from "Experimental set-up (pilot scale)", since dismantling them was not a possibility in our study. Three times (19 May, 7 June and 14 July), the earthworms were manually removed (from the two reactors containing them), to be counted and weighed.

\section{Data analysis}

One-way ANOVA was used to compare the effluent concentrations of the four mesocosms during the whole experimental period or during one season. Before this test was performed, the data were checked for normality and equal variance. When the assumptions were not met, the values were $\log _{10}$ transformed. If the assumptions were not met even after the transformation, ANOVA on ranks (Kruskal-Wallis) non-parametric test was used. The effect of earthworms (F vs. Fw and CW vs. $\mathrm{CWw}$ ) or plants (F vs. CW and $\mathrm{FW}$ vs. $\mathrm{CWw}$ ) on the wastewater treatment was tested with Student's $T$ test if the assumptions were met, or with Mann-Whitney $U$ test in the case when it was not possible even after $\log _{10}$ transformation. All the analyses were performed using SigmaPlot 13 software.

It should be mentioned that the sample size $(n)$ varied depending on the period of time considered in the statistical analysis. The size (for the same mesocosm and the same parameter) was larger when the whole experimental period was considered $(n=9-19)$, than when only one season was taken into account $(n=1-7)$. Groups with a sample size of 1 were not used for further analysis performed by ANOVA or $T$ test.

\section{Results and discussion}

\section{Growth capacity of earthworms in vertical flow reactors (microcosms)}

During the 2-month experimental period, the mass and number of earthworms decreased in both the reactor with earth-worms and in the one representing natural soil conditions: from 17 individuals to 1 and 7 , respectively (Table 2). It has been suggested that the number of earthworms in soil is pos-itively correlated to the soil OMC (van Vliet et al. 2007). Therefore, the large decrease observed in the reactor with earthworms (from 17 to 1) could have been caused possibly by a low OMC of its substrate.

The presence of earthworms did not have effect on the OMC of the substrate. From an OMC of $1.08 \%$, it reached $1.00 \%$ for the reactor with earthworms and $1.05 \%$ for the reactor without them (Table 2). These results could be explained by certain unfavourable conditions for the earthworms that could have caused the constant decrease of their popula-tion (Table 2). Hence, the addition of earthworms cannot be considered as a solution for the prevention or recuperation of clogged substrate in filters or CWs with a similar design to the ones used in this study.

\section{Performance of the pilot plant}

The average results of the whole experimental period are given in Table 3 . No significant difference $(p>$ 0.05; Table 3) was 
Table 2 Growth of earthworms in the reactors and their effect on the substrate's organic matter content ( $n=1$ unless stated differently)

\begin{tabular}{|c|c|c|c|c|c|}
\hline & & 5th May & 19th May & 7th June & 14th July \\
\hline \multirow[t]{3}{*}{ Reactor without earthworms } & Earthworm number & NA & NA & NA & NA \\
\hline & Earthworm mass (g) & NA & NA & NA & NA \\
\hline & Substrate OMC (\%) & 1.08 & & & 1.05 \\
\hline \multirow[t]{3}{*}{ Reactor with earthworms } & Earthworm number & 17 & 13 & 6 & 1 \\
\hline & Earthworm mass (g) & 3.051 & 2.451 & 0.990 & 0.155 \\
\hline & Substrate OMC (\%) & 1.08 & & & 1.00 \\
\hline \multirow[t]{3}{*}{ Reactor representing natural soil conditions (with earthworms) } & Earthworm number & 17 & 16 & 17 & 7 \\
\hline & Earthworm mass (g) & 3.041 & 2.086 & 2.107 & 1.072 \\
\hline & Substrate OMC (\%) & & & & \\
\hline Air temperature $\left({ }^{\circ} \mathrm{C}\right)^{\mathrm{a}}$ & Mean \pm st. error (n) & NA & $18.2 \pm 0.4(15)$ & $22.0 \pm 0.4(19)$ & $26.0 \pm 0.6(37)$ \\
\hline
\end{tabular}

All earthworms were counted and weighed. No differentiation was done between alive and dead individuals

$N A$ not applicable, OMC organic matter content

${ }^{a}$ Average air temperature in the period between the two dates (5 19 May, 19 May 7 June, and 7 June 14 July)

found between the effluent qualities of the four vertical flow mesocosms during the whole experimental period. The efflu-ent concentrations of TSS and COD did not statistically differ ( $p=0.865$ and 0.880 , respectively) and removal efficiencies were never below 80 and $65 \%$, respectively (Table 3). COD removal efficiency was higher than the 53\% removal reported by Sgroi et al. (2018) and in the range usually achieved by the vertical flow constructed wetlands enhanced with a recircula-tion step reviewed by $\mathrm{Wu}$ et al. (2014).

Effluent $\mathrm{pH}$ values increased as compared to the influent (from 6.65 to more than 7.12), while TN and TP removal efficiencies were in the range of $43-50 \%$ (Table 3 ). Nitrogen removal efficiency in this study is similar to that reviewed by Vymazal (2007) for several vertical flow constructed wetlands in different countries $(45 \%)$, and the phosphorus removal ef-ficiency was lower than the one given by the same author $(60 \%)$. Some studies added industrial by-products to the sub-strate in order to increase TP removal since those materials have higher phosphorus adsorption capacity than sand (Xu et al. 2006). For example, Zhao et al. (2011) achieved TP removal of almost $75-94 \%$ in the $\mathrm{CW}$ that contained alum sludge as the substrate. The low TP removal efficiency in this study can be a consequence of a low adsorption capacity of the substrate due to its grain size or low dissolved calcium con-tent, properties that mostly influence adsorption of phospho-rus on sand particles (Xu et al. 2006).

The removal of microorganisms (Table 3) was within the range (52-100\%) reported by Boutilier et al. (2009) for con-structed wetlands used for wastewater treatment. Some studies discussed in Molleda et al. (2008) found that a hydraulic re-tention time (HRT) of at least 2 days and a temperature of $20{ }^{\circ} \mathrm{C}$ is needed for the reduction of total coliforms of one logarithmic unit, and a HRT larger than 24 $\mathrm{h}$ for the reduction of two logarithmic units of $E$. coli. Similarly, the HRT was reported to be the most important factor affecting removal of indicator bacteria in constructed wetlands (Díaz et al. 2010). As the four mesocosms considered in this study had the same HRT, it is most likely the reason why no significant difference was found between them $(p>0.05$; Table 3) (Mancini 2017).

The lack of significant difference in the performance further implies that the presence of earthworms or plants cannot improve wastewater treatment efficiency in vertical flow filters with a similar design.

\section{Effect of earthworms}

\section{Wastewater treatment}

For all tested parameters, the four mesocosms' performance was statistically similar $(p>0.05$; Table 3$)$, and also no differ-ences were found when comparing $\mathrm{F}$ vs. $\mathrm{Fw}$ and $\mathrm{CW}$ vs. CWw for the whole experimental period ( $p$ $>0.05$; Table S.1). This suggests that the addition of earthworms at the given density $\left(0.1 \mathrm{~g} \mathrm{~L}_{\text {substrate }}{ }^{1}\right.$ or 0.25 individuals $\mathrm{L}_{\text {substrate }}{ }^{1}$ ) did not improve the treatment efficiency in either the filters or the constructed wetlands in this study. Similar conclusions were also found by Nuengjamnong et al.(2011), who conducted a study based on the application of earthworms in vertical flow constructed wetlands treating swine wastewater. On the other hand, Xu et al. (2013a) report-ed higher removals of COD, TN and TP in a constructed wetland containing earthworms than in the one without them. However, apart from the fact that the density of earthworms applied in that study was higher than in this one, the fish pond influent they used (COD, TN and TP concentrations of 8.02, 4.56 and $0.22 \mathrm{mg}$ $\mathrm{L}^{1}$, respectively) was considerably less polluted than the one used in this study, which probably pro-nounced the treatment contribution of the earthworms. Wu et al. (2013) also reported significantly higher removal efficiency of COD, TSS and TN in constructed wetlands 
Table 3 Performance of the pilot plant during the experimental period (October 2015 October 2016). All values are displayed as "mean \pm st. error (sample size)", except for $\mathrm{pH}$

\begin{tabular}{|c|c|c|c|c|c|c|c|c|c|c|}
\hline \multirow[t]{3}{*}{ Parameter } & \multirow{3}{*}{$\begin{array}{l}\text { Influent } \\
\text { Value }\end{array}$} & \multicolumn{8}{|l|}{ Effluent } & \multirow{3}{*}{$\begin{array}{l}\text { Statistics } \\
\text { ANOVA }^{\mathrm{a}} \\
p \text { value }\end{array}$} \\
\hline & & \multicolumn{2}{|l|}{ Filter $(F)$} & \multicolumn{2}{|c|}{$\begin{array}{l}\text { Filter with earthworms } \\
(\mathrm{Fw})\end{array}$} & \multicolumn{2}{|c|}{$\begin{array}{l}\text { Constructed wetland } \\
\text { with earthworms } \\
(\mathrm{CWw})\end{array}$} & \multicolumn{2}{|c|}{$\begin{array}{l}\text { Constructed wetland } \\
\text { (CW) }\end{array}$} & \\
\hline & & Value & $\operatorname{Re}(\%)$ & Value & $\operatorname{Re}(\%)$ & Value & $\operatorname{Re}(\%)$ & Value & $\operatorname{Re}(\%)$ & \\
\hline $\operatorname{COD}\left(\mathrm{mg} \mathrm{L}^{1}\right)$ & $886 \pm 74(13)$ & $300 \pm 42(15)$ & 66 & $308 \pm 39$ (14) & 65 & $283 \pm 39(15)$ & 68 & $263 \pm 32(15)$ & 68 & 0.880 \\
\hline $\operatorname{TSS}\left(\mathrm{mg} \mathrm{L}^{1}\right)$ & $168 \pm 28(10)$ & $31 \pm 4(18)$ & 81 & $31 \pm 5(16)$ & 82 & $31 \pm 4(19)$ & 81 & $33 \pm 4(18)$ & 80 & 0.865 \\
\hline $\mathrm{pH}$ & $6.65(7)$ & $7.40(11)$ & & $7.45(11)$ & & $7.12(11)$ & & $7.18(12)$ & & \\
\hline $\mathrm{TN}\left(\mathrm{mg} \mathrm{L}^{1}\right)$ & $65 \pm 6(18)$ & $34 \pm 6(16)$ & 48 & $36 \pm 6(16)$ & 45 & $33 \pm 7(17)$ & 50 & $33 \pm 6(17)$ & 49 & 0.848 \\
\hline $\mathrm{NO}_{3}-\mathrm{N}\left(\mathrm{mg} \mathrm{L}^{1}\right)$ & $0.85 \pm 0.12(19)$ & $0.99 \pm 0.41(17)$ & -14 & $0.42 \pm 0.12(17)$ & 51 & $0.39 \pm 0.08$ & 54 & $1.16 \pm 0.60(18)$ & -36 & 0.168 \\
\hline $\mathrm{NO}_{2}-\mathrm{N}\left(\mathrm{mg} \mathrm{L}^{1}\right)$ & $0.03 \pm 0.03$ & $0.02 \pm 0.02$ & 24 & $0.13 \pm 0.13$ & -77 & $0(18)$ & -54 & $0(18)$ & -24 & 1.000 \\
\hline $\mathrm{TP}\left(\mathrm{mg} \mathrm{L}^{1}\right)$ & $12.32 \pm 2.83(17)$ & $6.83 \pm 1.17(15)$ & 45 & $7.04 \pm 1.43$ & 43 & $6.66 \pm 1.14(15)$ & 46 & $6.50 \pm 1.18(15)$ & 47 & 0.947 \\
\hline $\mathrm{PO}_{4}{ }^{3}-\mathrm{P}\left(\mathrm{mg} \mathrm{L}^{1}\right)$ & $7.63 \pm 1.43$ & $5.55 \pm 0.79$ & 26 & $5.48 \pm 0.90$ & 27 & $5.36 \pm 0.93$ & 28 & $4.93 \pm 0.83(15)$ & 34 & 0.848 \\
\hline $\mathrm{Cl}\left(\mathrm{mg} \mathrm{L}^{1}\right)$ & $78 \pm 5(19)$ & $81 \pm 11(17)$ & -4 & $76 \pm 7(17)$ & 2 & $79 \pm 7(18)$ & -1 & $77 \pm 7(18)$ & 1 & 0.973 \\
\hline $\mathrm{Br}\left(\mathrm{mg} \mathrm{L}^{1}\right)$ & $2.56 \pm 0.35$ & $1.68 \pm 0.27$ & 34 & $4.51 \pm 2.50(17)$ & -76 & $6.32 \pm 4.09$ & -59 & $1.72 \pm 0.26(18)$ & 33 & 0.524 \\
\hline $\mathrm{SO}_{4}^{2}\left(\mathrm{mg} \mathrm{L}^{1}\right)$ & $69 \pm 5(19)$ & $53 \pm 8(17)$ & 23 & $66 \pm 9(16)$ & 3 & $59 \pm 9(18)$ & 14 & $66 \pm 9(18)$ & 3 & 0.672 \\
\hline $\begin{array}{l}\text { E. coli }\left(\log _{10} \mathrm{CFU}\right. \\
\left.100 \mathrm{~mL}^{1}\right)\end{array}$ & $5.69 \pm 5.02(10)$ & $5.01 \pm 4.49(10)$ & 79 & $4.86 \pm 4.24(9)$ & 85 & $5.10 \pm 4.56(10)$ & 74 & $5.09 \pm 4.56(10)$ & 75 & 0.620 \\
\hline $\begin{array}{l}\text { Total coliforms }\left(\log _{10}\right. \\
\left.\text { CFU } 100 \mathrm{~mL}^{1}\right)\end{array}$ & $5.85 \pm 5.81$ & $4.72 \pm 4.32(10)$ & 93 & $4.59 \pm 4.12(9)$ & 94 & $4.83 \pm 4.47(10)$ & 90 & $4.81 \pm 4.40(10)$ & 91 & 0.974 \\
\hline $\begin{array}{l}\text { Enterococcus }\left(\log _{10}\right. \\
\left.\quad \text { CFU } 100 \mathrm{~mL}^{1}\right)\end{array}$ & $5.51 \pm 4.59(10)$ & $5.14 \pm 4.67(10)$ & 57 & $5.20 \pm 4.81(9)$ & 51 & $5.20 \pm 4.75(10)$ & 51 & $5.21 \pm 4.76(10)$ & 50 & 0.975 \\
\hline
\end{tabular}

Removal efficiency (RE) was calculated with respect to the influent

${ }^{a}$ ANOVA $p$ values show the statistical comparison of the effluents from all four systems. The conducted tests were one way ANOVA or ANOVA on ranks

containing earthworms than in constructed wetlands used as controls. The substrate used in that study was coal cinders, and the systems were operated intermittently (loaded 6 times a day) with retention time of around 20 min-time needed for the wastewater to drain out of the system. That kind of system might have better operational conditions for the earthworms due to increased $\mathrm{OMC}$ and higher oxygen presence in the substrate compared to the mesocosms used in this study.

The densities of earthworms of $0.57 \mathrm{~g} \mathrm{~L}_{\text {substrate }}{ }^{1}, 32 \mathrm{~g}$ $\mathrm{L}_{\text {substrate }}{ }^{1}$ or 64 individuals $\mathrm{L}_{\text {substrate }}{ }^{1}$ and 3 individuals $\mathrm{L}_{\text {substrate }}{ }^{1}$ used by Nuengjamnong et al. (2011), Xu et al. (2013a) and Wu et al. (2013), respectively were higher than the density used in this study $\left(0.1 \mathrm{~g} \mathrm{~L}_{\text {substrate }}{ }^{1}\right.$ or 0.25 individuals $L_{\text {substrate }}{ }^{1}$ ). However, the earthworms in those studies were added only once, while in this one, it was done on a regular basis (every 3-4 weeks) in order to ensure the presence of earthworms in the substrate all the time. The short-term experiment presented in this manuscript ("Growth capacity of earthworms in vertical flow reactors (microcosms)") showed that the population of earthworms in a vertical filter decreased after 2 months, and in order to maintain their population, a regular addition of new individuals (like it was done with the Fw and the $\mathrm{CWw}$, "Experimental set-up (pilot scale)") should be performed.

Despite the constant addition of earthworms, the studied mesocosms might not have been a suitable living environment for them, according to the results obtained in " Growth capacity of earthworms in vertical flow reactors (microcosms)". Arora and Kazmi (2015) did report earth-worms' reproduction and growth in the filter, but it contained a substrate rich in organic matter that is not commonly used in constructed wetlands. Since the experimental period of the research presented here lasted 1 year, unfavourable conditions like temperatures outside of their optimal range of $25-30{ }^{\circ} \mathrm{C}$ could have hindered development of earthworms (Arora and Kazmi 2015) and could have prevented their effect on waste-water treatment in this study. Moreover, the coarse sand used as substrate might have had negative effect on the population of earthworms due to abrasive action of sand on their skin (Kanianska et al. 2016). Therefore, a regular addition of earth-worms into the system might be a valid approach since it can ensure maintaining their population number.

\section{Plant growth}

The dry weight of the above-ground biomass harvested in summer (June 2016) was 312 and $426 \mathrm{~g}$ for CW and CWw, respectively. At the end of the study (October 2016), the above-ground dry biomass was 360.5 and $505.5 \mathrm{~g}$, respective-ly. In addition, the longest plant shoot measured was 130 and $151 \mathrm{~cm}$, respectively. Thus, it can be suggested that the earth-worms have probably had an effect on the above-ground biomass and plant length. That is in accordance with $\mathrm{Xu}$ et al. (2012) who found that the introduction of earthworms 
into vertical flow constructed wetlands improved Iris pseudacorus growth and increased its dry weight. Moreover, $\mathrm{Xu}$ et al. (2013a, b, c) also reported similar results and stated that it can probably be attributed to the increased nutrient content of the substrate due to the presence of earthworms. Since the soil that passed through the earthworm's organism has more organic matter and available nutrients than the soil that did not go through this process (Le Bayon and Milleret 2009), it is probable that the presence of earthworms in the $\mathrm{CWw}$ improved the plant growth. Although Nuengjamnong et al. (2011) had found different results and ascribed it to a competition for food between the plants and earthworms, many other studies reviewed by the same author have reported a positive correlation between plant growth and presence of earthworms. Nevertheless, more harvesting campaigns are recommended to validate these findings.

\section{Effect of plants on wastewater treatment}

Although majority of studies shows that presence of plants positively affects the wastewater treatment (Vymazal 2011), similarly to earthworms, no significant difference on the treatment capacity was found between the planted and unplanted mesocosms of this particular design that included relatively small depth $(55 \mathrm{~cm})$ and batch operation $(p>0.05$; Table S.1).

Majority of the studies reviewed by Vymazal (2011) reported an increase in COD removal in the presence of plants, but no similar effect was observed in the case of TSS. Ouattara et al. (2011) also reported improved COD removal in vertical flow systems in the presence of plants, but they found that the plant effect on the TSS removal was negative. The authors attributed this negative effect on the TSS removal to the fact that plants can create different tunnels in the substrate through which solids can escape. Moreover, as those systems were located in Abidjan (Ivory Coast), a city with tropical climate, atmospheric conditions probably have caused higher plant growth than in this study, hence more pronounced effects. The lack of plant effect on COD and TSS removal in this study is in agreement with Collison and Grismer (2015) and Ciria et al. (2005), who explained it by the fact that it occurs mostly due to physical processes rather than biological ones.

No significant difference in the removal of TN was found between planted and unplanted mesocosms in this study (Table 3), which might be due to the fact that oxygen supplied by the plants was not high enough to show a visible increase in TN removal. Similar results were reported by Collison and Grismer (2015). On the other hand, the plants have bigger effect on TP removal than the substrate (Li et al. 2013), which is probably why the plants in this study had no significant effect on this parameter (Table 3 ).

Similar to this study, Torrens et al. (2009) and Headley et al. (2013) also did not report any significant difference between the removal of microbiological indicators (e.g. Faecal coliforms, E. coli) in planted and unplanted vertical flow filters. The authors attributed this result to the fact that removal of these organisms depends mostly on the HRT and the design of the system and therefore effect of the plants is not that notable. The same reason can explain the lack of significant effect of the plants on the pathogen's removal in this study.

\section{Seasonal differences}

No significant statistical difference was found between the four mesocosms during any of the four seasons ( $p>0.05$, Table S.2), suggesting that the different atmospheric conditions of the temperate climate did not influence their performance. Ciria et al. (2005) also did not find any difference in the constructed wetland's operation during the different seasons and explained it with the "venturi" mechanism, oxygen transport from the atmosphere to the substrate through the hollow plant stem. That mechanism would allow oxygenation of the substrate and it would enable activity of the microorganisms in the rhizosphere during the winter (when plants are dormant). Moreover, Sharma et al. (2013) also stated that the efficiencies of hybrid constructed wetland treating milking parlour wastewater in Japan was unaffected by seasonal differences. On the other hand, temperature was found to be an important factor affecting operation of CWs (Zhou et al. 2017; Zhu et al. 2018) but those stud-ies refer to climate zones where temperatures are much lower during the winter and therefore probably had more influence on different processes occurring in these systems.

Although nitrification process is temperature dependent and its rate increases with temperature (Huang et al. 2013), TN removal efficiency in this study did not differ during the different seasons. However, the minimal temperature for stable nitrification is $10^{\circ} \mathrm{C}$, and the process stops only when the temperature falls below $5^{\circ} \mathrm{C}$ (Huang et al. 2013). The average winter temperature during the experimental period in this study was $6.9{ }^{\circ} \mathrm{C}$ (Table 1) which would cause a low nitrification rate but that was probably compensated by the increased HRT ( 1 vs. 2 days) during the same period of the year (Table 1). The other three seasons had average temperatures above $10^{\circ} \mathrm{C}$ (Table 3) and therefore nitrification process probably did not vary (Huang et al. 2013). Removal efficiencies of the other parameters were probably not affected by the seasons since, for example, COD and TSS were mostly removed by physical processes (Ciria et al. 2005), TP by abiotic adsorption to the substrate ( $\mathrm{Li}$ et al. 2013), and pathogen removal was most likely more dependent on the system design and HRT than on other factors (Headley et al. 2013). 


\section{Conclusions}

The main goal of this study was to estimate how the presence of earthworms affects the removal efficiency and performance of planted and unplanted vertical flow wastewater treatment systems. It was found that earthworms, at the tested density $\left(0.1 \mathrm{~g} \mathrm{~L}_{\text {substrate }}{ }^{1}\right.$ added every few weeks), positively influence plant growth in constructed wetlands. However, neither earthworms nor plants showed a significant effect on the wastewater treatment in vertical flow systems in this study.

Earthworms at the density used in this study did not reduce the organic matter content of the reactor substrate and therefore they are probably not able to prevent clogging in similar set-ups (operated in a batch mode and with relatively shallow depth of $0.55 \mathrm{~m}$ ). This result could be also partly due to the fact that the studied filters do not prove to be a suitable living environment for the earthworms as compared to their natural environment. Therefore, some design improvements are needed in order to enable use of earthworms in similar systems (e.g. ambient temperature more adapted for their growth and reproduction).

The presence of earthworms at the tested density (10 individuals added every few weeks) did not show an effect on pollutant removal of vertical flow mesocosms treating wastewater. However, the results might differ if other experimental or design conditions are applied and therefore further research is needed.

Acknowledgements The first author's $\mathrm{PhD}$ scholarship was financed by the European Commission through Erasmus Mundus PhD in Marine and Coastal Management programme. The authors would like to thank Prof. Elena Fabbri from the University of Bologna for her help during the development of this project, and Dr. Marco Maglionico and Dr. Sara Simona Cipolla from CIRI (University of Bologna) for their contribution to the research.

\section{Compliance with ethical standards}

Conflict of interest The authors declare that they have no conflict of interest.

Publisher's note Springer Nature remains neutral with regard to jurisdic tional claims in published maps and institutional affiliations.

\section{References}

APHA (American Public Health Association) (2005) Standard methods for the examination of water and wastewater, 21st edn. American Public Health Association, Washington, D.C.

Arora S, Kazmi AA (2015) The effect of seasonal temperature on path ogen removal efficacy of vermifilter for wastewater treatment. Water Res 74:88 99

Boutilier L, Jamieson R, Gordon R, Lake C, Hart W (2009) Adsorption, sedimentation, and inactivation of $E$. coli within wastewater treat ment wetlands. Water Res 43(17):4370 4380
Chen Z, Hu S, Hu C, Huang L, Liu H, Vymazal J (2016) Preliminary investigation on the effect of earthworm and vegetation for sludge treatment in sludge treatment reed beds system. Environ Sci Pollut Res 23(12):11957 11963

Ciria MP, Solano ML, Soriano P (2005) Role of Macrophyte Typha latifolia in a constructed wetland for wastewater treatment and as sessment of its potential as a biomass fuel. Biosyst Eng 92(4):535 544

Collison RS, Grismer ME (2015) Nitrogen and COD removal from septic tank wastewater in subsurface flow constructed wetlands: plants effects. Water Environ Res 87(11):1999 2007

Díaz FJ, O'Geen AT, Dahlgren RA (2010) Efficacy of constructed wet lands for removal of bacterial contamination from agricultural return flows. Agric Water Manag 97(11):1813 1821

Edwards CA, Bater JE (1992) The use of earthworms in environmental management. Soil Biol Biochem 24(12):1683 1689

EN ISO 7899 2:2000: Water quality Detection and enumeration of intestinal enterococci Part 2: Membrane \#ltration method (ISO 7899 2:2000). Available online: https://onlinelibrary.wiley.com/ doi/full/10.1111/wej.12088. Accessed on 4th Nov 2018

Headley T, Nivala J, Kassa K, Olsson L, Wallace S, Brix H, van Afferden M, Müller R (2013) Escherichia coli removal and internal dynamics in subsurface flow ecotechnologies: effects of design and plants. Ecol Eng 61(part B):564 574

Huang J, Wenshu C, Zhong Q, Wang S (2013) Influence of temperature on micro environment, plant eco physiology and nitrogen removal effect in subsurface flow constructed wetland. Ecol Eng 60:242 248

Kanianska R, Jad'ud'ová J, Makovníková J, Kizeková M (2016) Assessment of relationships between earthworms and soil abiotic and biotic factors as a tool in sustainable agricultural. Sustainability 8(9):906

Lavrnić S, Mancini ML (2016) Can constructed wetlands treat wastewa ter for reuse in agriculture? Review of guidelines and examples in South Europe. Water Sci Technol 73(11):2616 2626

Le Bayon RC, Milleret R (2009) Effects of earthworms on phosphorus dynamics a review. Dyn Soil Dyn Plant 3(2):21 27

Li HZ, Wang S, Ye JF, Xu ZX, Jin W (2011) A practical method for the restoration of clogged rural vertical subsurface flow constructed wetlands for domestic wastewater treatment using earthworm. Water Sci Technol 63(2):283 290

Li H, Li Y, Gong Z, Li X (2013) Performance study of vertical flow constructed wetlands for phosphorus removal with water quenched slag as a substrate. Ecol Eng 53:39 45

Mancini B (2017) Application of sequence based typing (SBT) technique to typing strains of legionella spp.: development of an environmen tal risk map. $\mathrm{PhD}$ thesis. University of Bologna. Bologna, Italy

Matos GD, Arruda MAZ (2003) Vermicompost as natural adsorbent for removing metal ions from laboratory effluents. Process Biochem 39(1):81 88

Meng P, Pei H, Hu W, Shao Y, Li Z (2014) How to increase microbial degradation in constructed wetlands: influencing factors and im provement measures. Bioresour Technol 157:316 326

Molleda P, Blanco I, Ansola G, de Luis E (2008) Removal of wastewater pathogen indicators in a constructed wetland in Leon, Spain. Ecol Eng 33(3):252 257

Ngo PT, Rumpel C, Doan TT, Jouquet P (2012) The effect of earthworms on carbon storage and soil organic matter composition in tropical soil amended with compost and vermicompost. Soil Biol Biochem 50:214 220

Nivala J, Knowles P, Dotro G, García J, Wallace S (2012) Clogging in subsurface flow treatment wetlands: measurement, modeling and management. Water Res 46(6):1625 1640

Nuengjamnong C (2010) Implementation of earthworm assisted con structed wetlands to treat wastewater and possibility of using alter native plants in constructed wetlands. PhD thesis. Hamburg University of technology. Hamburg, Germany 
Nuengjamnong C, Chiarawatchai N, Polprasert C, Otterpohl R (2011) Treating swine wastewater by integrating earthworms into con structed wetlands. J Environ Sci Health A Tox Hazard Subst Environ Eng 46(7):800 804

Ouattara JMP, Coulibaly L, Tiho S, Ouattara A, Goure G (2011) Panicum maximum (Jacq.) density effect upon macrofauna structure in sedi ments of pilot scale vertical flow constructed wetlands treating do mestic wastewater. Ecol Eng 37(2):217 223

Sgroi M, Pelissari C, Roccaro P, Sezerino PH, García J, Vagliasindi FGA, Ávila C (2018) Removal of organic carbon, nitrogen, emerging contaminants and fluorescing organic matter in different constructed wetland configurations. Chem Eng J 332:619 627

Sharma PK, Takashi I, Kato K, Ietsugu H, Tomita K, Nagasawa T (2013) Seasonal efficiency of a hybrid sub surface flow constructed wet land system in treating milking parlor wastewater at northern Hokkaido. Ecol Eng 53:257 266

Singh RP, Fu D, Jia J, Wu J (2018) Performance of earthworm enhanced horizontal sub surface flow filter and constructed wetland. Water 10(10): 1309

Tamis J, van Schouwenburg G, Kleerebezem R, van Loosdrecht MC (2011) A full scale worm reactor for efficient sludge reduction by predation in a wastewater treatment plant. Water Res 45(18):5916 5924

Tanner CC, Sukias JP (1995) Accumulation of organic solids in gravel bed constructed wetlands. Water Sci Technol 32(3):229 239

Taylor M, Clarke WP, Greenfield PF (2003) The treatment of domestic wastewater using small scale vermicompost filter beds. Ecol Eng 21(2 3):197 203

Tomar P, Suthar S (2011) Urban wastewater treatment using vermi biofiltration system. Desalination 282:95 103

Torrens A, Molle P, Boutin C, Salgot M (2009) Removal of bacterial and viral indicator in vertical flow constructed wetlands and intermittent sand filters. Desalination 246(1):169 178

UNI EN ISO 9308 1:2014/A1:2017 Water quality Enumeration of Escherichia coli and coliform bacteria Part 1: Membrane \#ltration method for waters with low bacterial background 5ora (ISO 9308 1: 2014/Amd1:2016). Available online: http://store.uni.com/catalogo/ index.php/uni en iso 93081 2017.html. Accessed on 7 Nov 2018

van Vliet PCJ, van der Stelt B, Rietberg PI, de Goede RGM (2007) Effects of organic matter content on earthworms and nitrogen min eralization in grassland soils. Eur J Soil Biol 43(1):S222 S229

Vymazal J (2007) Removal of nutrients in various types of constructed wetlands. Sci Total Environ 380(1 3):48 65
Vymazal J (2011) Plants used in constructed wetlands with horizontal subsurface flow: a review. Hydrobiologia 674(1):133 156

Wu L, Li X, Song H, Wang G, Jin Q, Xu X, Gao Y (2013) Enhanced removal of organic matter and nitrogen in a vertical flow construct ed wetland with Eisenia foetida. Desalin Water Treat 51(40 42): 74607468

Wu S, Kuschk P, Brix H, Vymazal J, Dong R (2014) Development of constructed wetlands in performance intensifications for wastewater treatment: a nitrogen and organic matter targeted review. Water Res $57: 4055$

Xu D, Xu J, Wu J, Muhammad A (2006) Studies on the phosphorus sorption capacity of substrates used in constructed wetland systems. Chemosphere 63(2):344 352

Xu DF, Li YX, Zheng JW, Guan YD, Fang H (2012) Effects of earth worms and substrate on Iris pseudacorus growth. Adv Mater Res $550553: 14291434$

Xu D, Li Y, Fan X, Guan Y, Fang H, Zhao L (2013a) Influence of earthworm Eisenia fetida on Iris pseudacorus's photosynthetic char acteristics, evapotranspiration losses and purifying capacity in con structed wetland systems. Water Sci Technol 68(2):335 441

Xu D, Li Y, Howard A (2013b) Influence of earthworm Eisenia fetida on removal efficiency of $\mathrm{N}$ and $\mathrm{P}$ in vertical flow constructed wetland. Environ Sci Pollut Res 20(9):5922 5929

Xu D, Li Y, Howard A, Guan Y (2013c) Effect of earthworm Eisenia fetida and wetland plants on nitrification and denitrification poten tials in vertical flow constructed wetland. Chemosphere 92(2):201 206

Zapater Pereyra M, Ilyas H, Lavrnić S, van Bruggen JJA, Lens PNL (2015) Evaluation of the performance and space requirement by three different hybrid constructed wetlands in a stack arrangement. Ecol Eng 82:290 300

Zhao YQ, Babatunde AO, Hu YS, Kumar JLG, Zhao XH (2011) Pilot field scale demonstration of a novel alum sludge based constructed wetland system for enhanced wastewater treatment. Process Biochem 46:278 283

Zhou Q, Hui Z, Bañuelos G, Yan B, Liang Y, Jing Y, Li H (2017) Impacts of vegetation and temperature on the treatment of domestic sewage in constructed wetlands incorporated with ferric carbon micro elec trolysis material. Int J Phytoremedia 19(10):915 924

Zhu H, Zhou Q W, Yan B X, Liang Y X, Yu X F, Gerchman Y, Cheng X W (2018) Influence of vegetation type and temperature on the per formance of constructed wetlands for nutrient removal. Water Sci Technol 77(3 4):829 837 